\title{
Does Profitability, Firm Size, and Macroeconomic Variable Affect Yield to Maturity of Corporate Sukuk?
}

\author{
Suci Aprilliani Utami ${ }^{1}$ Yana Rohmana ${ }^{2}$ \\ ${ }^{1}$ Program Studi Ilmu Ekonomi dan Keuangan Islam, FPEB, Universitas Pendidikan Indonesia, Bandung, Indonesia \\ ${ }^{2}$ Program Studi Pendidikan Ekonomi, FPEB, Universitas Pendidikan Indonesia, Bandung, Indonesia
}

\begin{abstract}
The purpose of of this research is to examine the influence of profitability, firm size, and macroeconomic variable on the yield to maturity of corporate sukuk. The yield to sukuk maturity that will be received by investors illustrates the level of investor profit but the yield level also describes the level of risk borne by investors. This research was conducted on all companies listed on the Indonesia Stock Exchange in the 2015-2018 period which issued sukuk ijarah and published its financial statements during the research period. The research samples is $54^{\text {th }}$ ijarah sukuk This research was conducted using a quantitative approach with panel data. The data analysis technique used in this study is panel data regression with a fixed effect model. The results showed that profitability projected with Return on Asset did not affect the yield to maturity of sukuk ijarah, the size of the firm negatively affected the yield to maturity of sukuk ijarah, the BI-Rate variable had a positive and significant effect on yield to maturity of sukuk and inflation had a negative effect on yield of ijarah sukuk. This finding accordance with the existing theories that factor affecting yield to maturity of corporate sukuk can be detected by the influence of microeconomic and macroeconomic variable.
\end{abstract}

Keyword. yield to maturity; al-ijarah sukuk; profitability; firm size; bi 7 days rate; inflation

Article History. Received August, 2019. Revised October, 2019.Accepted December, 2019

Corresponding Author. Email. suci.avril@upi.edu, rohmanayana@upi.edu

How to cite article. Aprilliani, S., \& Yana, U. (2019). Does Profitability , Firm Size, and Macroeconomic Variable Affect Yield to Maturity of Corporate Sukuk? The International Journal of Business Review (The Jobs Review), 2(2), 75-88.

https://doi.org/https://doi.org/10.17509/tjr.v2i2.20921

\section{INTRODUCTION}

Corporate Islamic bonds, or better known as corporate sukuk is one of investment instrument that is developing in the Islamic capital market. Since the issuance of the National Sharia Council (DSN), the Indonesian Ulema Council (MUI) in 2002 issued Fatwa No.32 / DSN-MUI / IX / 2002 concerning Sharia Bonds, since then sukuk began to grow and develop side by side with conventional bonds. According to the Otoritas Jasa Keuangan or Financial Services Authority Regulation Number 18 / POJK.04 / 2015, Sukuk are Sharia Securities in the form of certificates or proof of ownership of the same value and represent an inseparable or undivided share of the underlying assets (Otoritas Jasa Keuangan, 2015).

The sukuk market is likely going to experience year-over-year growth, and the future of the market looks bright. As the market develops, the private sector will become increasingly interested. The market is expected to maintain high levels of liquidity, which will continue to drive interest among financial institutions. Furthermore, according to (Hassan, n.d.), many corporations are currently sitting on the sidelines to venture into the sukuk market, as they start to seek a more diverse investor base beyond the traditional bank lending market. 
Nowadays, the functions of sukuk have differed. A simple explanation of modern sukuk is that sukuk are financial in- struments that allow market players to obtain a large amount of cash or capital from investors. It can be done via developing a various structure of sukuk with underlying property or assets. The bonds process involves lenders and borrowers while the sukuk process involves the sukuk issuers and the investors via Islamic contracts. Sukuk issuers will securitise assets to issue sukuk. Investors who are interested to subscribe or buy the sukuk will get a certificate which represents ownership of the asset, risk, and cash flows. Upon maturity, those investors are entitled to get money equivalent to the value of the sukuk. The value of sukuk could be varied according to the value of the asset that is backing them. That criteria differentiate sukuk from bonds(Razak et al., 2018).

The first definition of modern-day sukuk was given in 1988 during the fourth session of the Council of the Islamic fiqh academy in Jeddah. This resolution was on mudharabah sukuk (trust based Islamic bond) (Razak et al., 2018). According to (IIFM Sukuk Report. (2018)., 2019) the global sukuk issuance during 2018 stood at USD 123.2 billion, which is a modest increase 5,5\% over 2017 primary market Sukuk issuances of USD 116.7 billion. The annual sukuk report notes that currently $90.44 \%$ of the USD 443.78 billion sukuk outstanding globally are issued from few well established markets namely, Malaysia, Saudi Arabia, UAE, Indonesia and Bahrain while other countries lie Pakistan, Qatar, Turkey, Oman and regions such as Africa in particular are likely to gradually increase their market share in the coming years. The report identifies that the global sukuk (with issue size of 100 million or above and with tenor of more than year) set to mature during 2019 and 2020 will be around USD 73.4 billion.

In Indonesia, sukuk with an ijarah agreement are sukuk that have depeloped well. Ijarah sukuk has a simpler structure compared to mudharabah sukuk. Sukuk Ijarah is considered a flexible structure, and can be used for various financing needs. In addition, Ijarah Sukuk is truly negotiable and therefore can be traded on the secondary market, because this Sukuk certificate represents ownership in real assets. As a result, many Sukuk issuers chose the Ijarah structure. Sukuk Ijarah is issued by companies, governments, government organizations and other organizations (Nisar., 2010).

Theoritical studies and focuses mainly on explaining and developing sukuk structures with an emphasis on legal consideration is the most of the research on sukuk instrument (Alam et al., 2013)(Abdel-Khaleq, A. H., \& Richardson, 2007)(Bhuiyan et al., 2018). The existing literature also focused on the empirical and among other or legal, shariah, regulator, supervisory (Naifar, 2016)(Oseni, U.\&Hassan, 2015)(Zulkhibri, 2015)(Boutti, 2014). This research examine the influence of profitability, firm size, BI 7 days rate on yield to maturity of sukuk with an ijarah agreement.

According to data obtained from sukuk report 2018 (IIFM Sukuk Report. (2018)., 2019), the average yield to maturity in the sukuk ijarah secondary market has decrease in the last 5 years until 2018. The yield of maturity is called the internal rate of return (Krichene, 2012). The decrease of yield to maturity indicates that the level of profit gained if the sukuk is bought at the present time will get lower compound return from previous years. Yield to maturity is most widely used as a measure of yield because it can reflect returns with compounded rates of return expected by investors if the two assumptions required can be met. The first assumption is that investor will hold the maturity. The second assumption is that investors reinvest income derived from bonds at the yoeld level of maturity generated. If both assumption are fulfilled, the expected yield to maturity will be the same as realized yield. If coupon revenue is not invested at the same level as yield to maturity, the yield to maturity obtained will be smaller or grater than the yield promised. 
Profitability ratios assess a firms ability to find profit. Several research show that profitability ratios have influenced the yield to maturity sukuk or yield to maturity bonds with the type of fixed return. Inflation is a macro variable that has a great influence on economic activity in the capital market. Tandelilin (Tandelilin, 2017) explained that the risk of inflation will cause a decrease in the real income. In the context of debt securities, an increase in inflation will cause a decrease in the real value of the bond yields obtained by investors during the life of the bonds. BI-Rate is one of the macro variables that shows its influence on yield to maturity of sukuk and bonds with fixed return.

Most of the previous studies documented in literature that sukuk serve as a crucial tool for resource mobilization and a key instrument for the development of Islamic financial market (Jobst et al., 2008) (Wilson, 2008). Other previous studies on sukuk yields are focuses mainly on examine sukuk yields and bond yields that use bond samples with fixed rates because they have same pattern of returns with sukuk ijarah yields or coupon rate does not changethroughout the period of validity of the sukuk or bond. in addition, previous research that discusses the price of debt securities is still in line because according to the theory of the relationship of yields with the price of bonds in opposite directions, where when the yield rises, bond prices will fall, and vice versa (Haryanto, 2012).

In the recent years, some empirical studies are devoted either to research on structured sukuk instruments with case studies or research on macroeconomic influences on sukuk issuance (Ahmad et al., 2012). Other studies introduce the effects of stock market in explaining sukuk yield dynamics. Naifar and Mseddi (2013) analyse the links between sukuk yield yields, stock market conditions and macroeconomic variables in the case of United Arab Emirates (thereafter UAE) by using linear regression. They find that sukuk yield spread react positively to stock market implying that an increase in stock index return is accompanied with an increase in sukuk yield yields (Naifar, N., \& Mseddi, 2013)

In other research, (Naifar, 2016) investigate the dependence structure between sukuk (Islamic bonds) yields and stock market (returns and volatility) in the case of Saudi Arabia. The researcher consider three Archimedean copula models with different tail dependence structures namely Gumbel, Clayton, and Frank. This study shows that the sukuk yields exhibit significant dependence only with stock market volatility. In addition, the dependence structure between sukuk yields and stock market volatility are symmetric and linked with the same intensity.

Rahman et.al studies show the essential to analyze whether the sovereign sukuk yields do reflect the macroeconomic fundamentals of the issuing country. Based on the analysis of five countries in Asia and the Middle East, this study employs panel data from 2006 to 2013 and shows that only the inflation rate is able to explain the movement of sovereign sukuk yields. The insignificance of other macroeconomic variables such as GDP growth and money supply indicate that tagging the economic growth of the issuing country onto the pricing of sovereign sukuk yields may not be feasible at this juncture. Hence, it is concluded that in order to develop a standalone pricing mechanism different from the one used by the conventional bond market, more efforts are needed so that the sukuk market will expand with even more market player pa rticipation to create the liquidity needed for it to develop its own pricing mechanism (Puspa \& Duasa, 2017). Other studies proposes a framework to explain the main macroeconomic determinants of SMD with a focus on the GCC countries that have the largest region in terms of the Islamic financial assets. It is anticipated that the outcome will support policymakers to improve the current state of Sukuk market (Al-raeai et al., 2018).

As the above literature recommend, sukuk yields can be linked to stock market conditions and macroeconomics conditions. Our study differs from previous studies. First 
we model the factors that influence sukuk through the financial performance, firm size and macroeconomics variable in the case of Indonesia. Second, we use sukuk al-ijarah because the al- ijarah contract is a rental contract based Islamic bond. Al- ijarah sukuk are among the most significant sukuk in the market. It is a popular contract among IFIs due to its similarity to a conventional lease. In ijara contract, one party purchases and leases the equipment required by the client for a rental fee.

The duration of the rental and the fee are agreed in advance, and ownership of the asset remains with the lessor. An example of the application of ijara in Islamic banking product can be seen in house financing. The bank purchases a house for a customer. The customer then pays a rental fee until the total cost has been paid, at which point the asset is transferred to the customer. The expected return on some forms of ijara may not be completely fixed and determined in advance since there might be some maintenance and insurance expenses that are difficult to determine up front. This characteristic has made the contract become negotiable and can be traded on the secondary market. Now it is time to understand how al-ijara sukuk works. Ijara sukuk refers to the securities representing ownership of well-defined existing and known assets tied up to a lease contract of which is the return payable to sukuk holders (Naifar, 2016).

Payment of ijara rentals can be unrelated to the period of taking usufruct by the lessee. It can be made before the beginning of the lease period, during the period or after the period so long as both parties have mutually decided. This flexibility can be used to evolve different forms of contracts and sukuk that may serve different purposes. In ijara sukuk, an issuer is usually in the form of a special purpose vehicle (SPV) or a trust issues sukuk to finance a purchase of one or more assets from the obligor, the financed party. The assets will then be leased to a lessee whose lease payments will be in the form of periodic payments to the investors (sukuk holders). At maturity, the asset will be repurchased by the obligor at a predetermined price, and the proceeds of this sale will be transferred to the sukuk holders (Naifar, 2016).

\section{METHOD}

The research method in this study uses a quantitative approach, according to Ferdinand (Ferdinand, 2014) quantitative research in which to find new concepts or theses, researchers first develop proportions and hypotheses to the next step then be tested with quantitative data until finally arriving at the final findings in the form of a new theses or tested hypotheses, then research like this is called hypothesis testing research. Meanwhile according to Noor (Noor, 2017) quantitative research is a method for testing certain theories by examining the relationships between variables. These variables are measured (usually with research instruments) so data consisting of numbers can be analyzed based on statistical procedures. The population in this study was corporate sukuk that circulated in Indonesia.

The sample criteria in this study are follows: (1) Sukuk that uses an ijarah agreement as reported in 2015-2018 and is listed in the Indonesia Stock Exchange (2) Sukuk whose issue publishes its financial statements.

Table 1. Sample Criteria

\begin{tabular}{lc}
\hline \multicolumn{1}{c}{ Description } & Amount \\
\hline Ijarah contract sukuk circulating during the observation period & 57 \\
Sukuk whose publishers do not publish their financial statements & 3 \\
\hline
\end{tabular}

78 | The International Journal of Business Review (The Jobs Review) Vol.2 | No.2 | 2019 


\begin{tabular}{lc}
\hline Number of Sukuk Samples & 54 \\
\hline
\end{tabular}

Source: (Indonesia Bond Pricing Agency, 2019)

The sukuk that were sampled were 54 ijarah sukuk from 10 companies that published their financial statements. Because there are many sukuk that have a due date or time of publication in the middle of the observation period, so the type of data in this study includes unbalanced data, the number of observations is 120 observations. In table 2 is a list of sukuk used as samples in this study.

In this study the data used are secondary data that has been previously processed and sourced from statistical data published by: (1) Financial Services Authority (2) Indonesia Stock Exchange (IDX) (3) Indonesia Bond Pricing Agency (IBPA) (4) Company Financial Reports (5) Bank Indonesia

Table 2. Sample List Based on The Company which Publishes its Financial Statements

\begin{tabular}{|c|c|c|c|}
\hline NO & SUKUK CODE & NO & SUKUK CODE \\
\hline 1 & PPLN08C & 31 & SIAPAI01A \\
\hline 2 & SIAGII02 & 32 & SIAPAI01B \\
\hline 3 & SIISAT01ACN1 & 33 & SIAPAI01C \\
\hline 4 & SIISAT01BCN1 & 34 & SIEXCL01ACN2 \\
\hline 5 & SIISAT01CCN1 & 35 & SIEXCL01BCN2 \\
\hline 6 & SIPPLN01CN1 & 36 & SIEXCL01CCN2 \\
\hline 7 & SIPPLN01ACN2 & 37 & SIEXCL01DCN2 \\
\hline 8 & SIPPLN01BCN2 & 38 & SIEXCL01ECN2 \\
\hline 9 & SISMRA01CN1 & 39 & SIISAT02ACN1 \\
\hline 10 & SISMRA01CN1 & 40 & SIISAT02BCN1 \\
\hline 11 & SIKISAT04B & 41 & SIISAT02CCN1 \\
\hline 12 & SIISAT05 & 42 & SIISAT02DCN1 \\
\hline 13 & SIKMAPI01B & 43 & SIISAT02ACN2 \\
\hline 14 & SIKPPLN03A & 44 & SIISAT02BCN2 \\
\hline 15 & SIKPPLN03B & 45 & SIISAT02CCN2 \\
\hline 16 & SIKPPLN04B & 46 & SIISAT02DCN2 \\
\hline 17 & SIKSIMP01 & 47 & SIISAT02ECN2 \\
\hline 18 & SIAISA01 & 48 & SIPPLN02ACN1 \\
\hline 19 & SIISAT01BCN2 & 49 & SIPPLN02BCN1 \\
\hline 20 & SIISAT01CCN2 & 50 & SIPPLN02ACN2 \\
\hline 21 & SIISAT01DCN2 & 51 & SIPPLN02BCN2 \\
\hline 22 & SIISAT01ECN2 & 52 & SIPPLN02CCN2 \\
\hline 23 & SISMRA01CN3 & 53 & SITINS01ACN1 \\
\hline 24 & SIAISA02 & 54 & SITINS01BCN1 \\
\hline 25 & SIEXCL01BCN1 & & \\
\hline 26 & SIEXCL01CCN1 & & \\
\hline 27 & SIEXCL01DCN1 & & \\
\hline 28 & SIISAT01BCN4 & & \\
\hline
\end{tabular}

79 | The International Journal of Business Review (The Jobs Review) Vol.2 | No.2 | 2019 


\section{SIISAT01CCN4 \\ $30 \quad$ SIISAT01DCN4}

Data analysis in this study used the analysis of influence test through panel data regression test. Panel data regression test in this study combines time series with cross sections into one observation. Panel data is a combination of time series data and cross section data (Rohmana, 2013). According to Ekananda (Ekananda, 2014) in econometric theory, the process of integrating data between time and between individuals is called pooling. While the data generated is called pooled data or panel data or longitudinal data.

\section{RESULTS AND DISCUSSION}

\section{Yield to Maturity Sukuk Ijarah}

In the capital market is the most important factor that must be used by investors as consideration in buying sukuk as an investment instrument, namely yield to maturity. Yieldto-maturity yields in this study use the Yield-to-maturity measure of corporate sukuk as of December 31, 2015-2018, Yield to Maturity data in this study were obtained from the Indonesian Bond Pricing Agency.

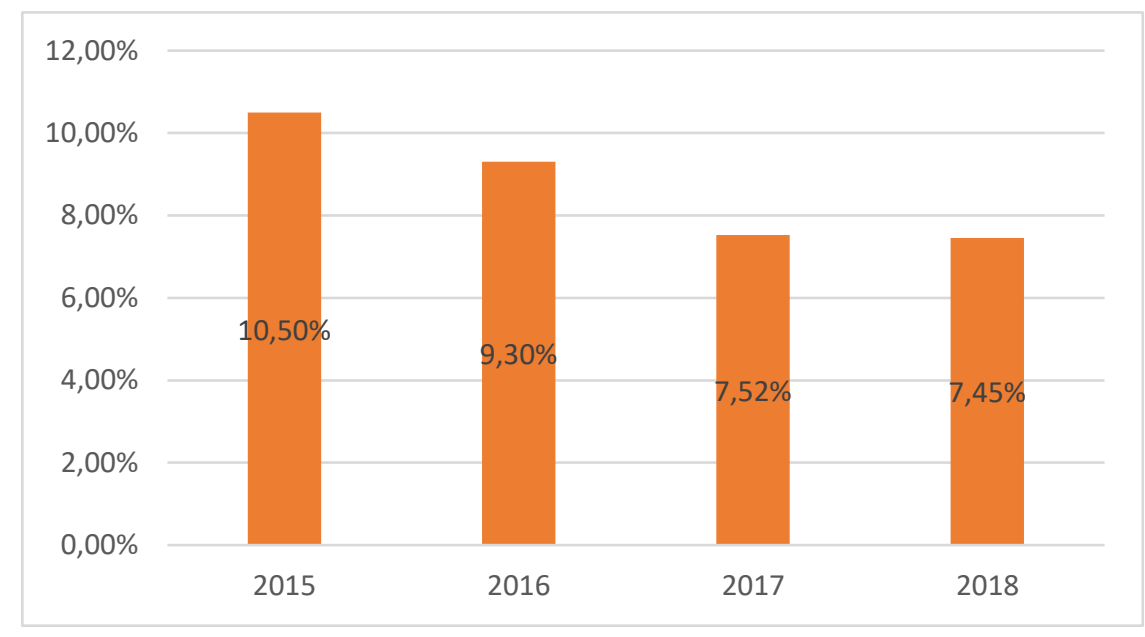

Source: (Indonesia Bond Pricing Agency, 2019)

Figure. 1 Yield to Maturity Sukuk Ijarah per Desember 2015-2018

Based on Table 3 the highest yields to maturity were produced by sukuk from Summarecon Agung with $10.8 \%$ with the sukuk code SISMRA01CN1, and the lowest average yield to maturity is generated by PT. Indosat with the SIISAT02ACN2 sukuk code with a yield to maturity of $6.12 \%$.

Tabel 3. Description of Data Yield to Maturity Sukuk

\begin{tabular}{llc}
\hline The Highest Yield to maturity & $\begin{array}{l}\text { PT.Summaecon } \\
\text { (SISMRA01CN1) }\end{array}$ & $12,6 \%$ \\
The Lowest Yield to maturity & $\begin{array}{l}\text { PT.Indosat } \\
\text { (SIISAT01ACN1) }\end{array}$ & $5,7 \%$ \\
Highest Average Yield to maturity & PT. Summarecon & $10,8 \%$ \\
\hline
\end{tabular}

80 | The International Journal of Business Review (The Jobs Review) Vol.2 | No.2 |2019 


\begin{tabular}{lll}
\hline Lowest Average Yield to maturity & PT. Indosat & $6,1 \%$ \\
\hline
\end{tabular}

Source: (Indonesia Bond Pricing Agency, 2019)

\section{Profitability}

Profitability used in this research is profitability by using the Return on Asset proxy. The profitability of each company has fluctuated, in 2015 there were 4 companies that experienced a decrease in profitability, namely the PLN, Summarecon, Three Pillars and Various Gas Industries. And the increase experienced by Indosat companies. Meanwhile in 2016 many companies experienced an increase in profitability, namely PLN, Indosat, Tiga Pilar, XL and Aneka Gas companies. But the decline occurred at PT. Summarecon. Meanwhile in 2017 Summarecon Agung continued to experience a decline in profitability and several other companies such as PLN, Tiga Pilar, Angkasa Pura, XL also experienced a decline. However, the extremely extreme decrease in profitability in 2017 was experienced by Tiga Pilar Sejahtera Food from $7.77 \%$ to $-9.71 \%$.

Table 4. Emiten Profitability 2015-2018

\begin{tabular}{|c|c|c|c|c|}
\hline \multirow{2}{*}{ Company } & \multicolumn{4}{|c|}{ Years } \\
\hline & 2015 & 2016 & 2017 & 2018 \\
\hline PLN & $0,46 \%$ & $0,64 \%$ & $0,33 \%$ & $0,77 \%$ \\
\hline Summarecon & $5,67 \%$ & $2,91 \%$ & $2,46 \%$ & $0,39 \%$ \\
\hline Indosat & $-2,10 \%$ & $2,51 \%$ & $2,57 \%$ & $3,92 \%$ \\
\hline Timah & & & $6,54 \%$ & $3,51 \%$ \\
\hline Tiga Pilar & $4,12 \%$ & $7,77 \%$ & $\stackrel{-}{9,71 \%}$ & \\
\hline XL & $-0,04 \%$ & $0,68 \%$ & $0,67 \%$ & $0,49 \%$ \\
\hline $\begin{array}{l}\text { Angkasa Pura } \\
\text { Mitra Adi Perkasa }\end{array}$ & & $6,93 \%$ & $6,16 \%$ & $6,44 \%$ \\
\hline Salim Ivomas & & & & $7,08 \%$ \\
\hline Aneka Gas & $0,97 \%$ & $1,10 \%$ & $1,52 \%$ & $1,72 \%$ \\
\hline Yearly Average & $1,51 \%$ & $3,22 \%$ & $1,32 \%$ & $3,04 \%$ \\
\hline The Highest & $5,67 \%$ & & & $6,54 \%$ \\
\hline The Lowest & $-2,10 \%$ & & & $-9,71 \%$ \\
\hline
\end{tabular}

Source: Each Sukuk Ijarah Issuer's Financial Report

According to Table 4. the highest profitability of the ten companies that issued sukuk in the research year was PT. Tiga Pilar with profitability of $7.77 \%$ in 2016 and the lowest profitability held by PT. Tiga Pilar in 2017 namely $-9.71 \%$. Meanwhile, the average profitability of companies issuing sukuk in the research year fluctuated with the highest average profitability occurring in 2016 and the lowest in 2017.

\section{Firm Size}

The size of the company is measured by the total assets owned by the issuer. The total assets owned by sukuk issuers in the study period fluctuated. But in 2018 all companies issuing 
sukuk experienced an increase in total assets owned. Meanwhile in 2016 the companies PLN, Indosat and XL experienced a decrease in total assets in the year from the previous year. Meanwhile in 2017 the decline in total assets was only experienced by Indosat and Tiga Pilar.

Table 5. Emiten Firm Size 2015-2018

\begin{tabular}{|c|c|c|c|c|}
\hline \multirow[b]{2}{*}{ Company } & \multicolumn{4}{|c|}{ Years } \\
\hline & 2015 & 2016 & 2017 & 2018 \\
\hline PLN & Rp.1.314.370.881 & Rp.1.272.177.975 & Rp.1.334.957.657 & Rp. 1.492 .490 .000 \\
\hline Summarecon & Rp.18.758.262 & Rp.20.810.319 & Rp.21.662.712 & Rp. 21.737 .917 \\
\hline Indosat & Rp . 55.388.517 & Rp.50.838.704 & Rp.50.661.040 & Rp. 53.139.587 \\
\hline Timah & & & Rp.11.876.309 & Rp. 117.948.000 \\
\hline Tiga Pilar & Rp.9.060.979 & Rp.9.254.539 & Rp.8.724.734 & \\
\hline $\mathrm{XL}$ & Rp.58.844.320 & Rp.54.896.286 & Rp.56.321.441 & Rp. 57.613.954 \\
\hline Angkasa Pura & & Rp.27.991.218 & Rp.32.651.959 & Rp. 38.520 .000 \\
\hline Mitra Adi & & & & Rp. 12.632 .671 \\
\hline Salim Ivomas & & & & Rp. 34.666.506 \\
\hline Aneka Gas & Rp.4.953.451 & Rp.5.847.722 & Rp.6.403.543 & Rp. 6.647 .755 \\
\hline Yearly Average & Rp.243.562.735 & Rp.205.973.823 & Rp.190.407.424 & Rp. 203.932.932 \\
\hline The Highest & Rp.1.314.370.881 & Rp.1.272.17.975 & Rp. 1.334.957.657 & Rp. 1.492 .490 .000 \\
\hline Lowest & Rp. 4.953 .451 & Rp. 5.847.722 & Rp.6.403.543 & Rp. 6.647 .755 \\
\hline
\end{tabular}

Source: Each Sukuk Ijarah Issuer's Financial Report

According to Table 5, the smallest company size of 4.9 trillion is owned by PT. Aneka Gas Industri at the beginning of the research period in 2015, but positive growth continued to occur in the total assets owned by PT. Aneka Gas Industri from 4.9 trillion in 2015 rise to 5.8 trillion and in 2016 to 6.4 trillion and in 2017 to 6.6 trillion. Aneka Gas company recorded positive growth in the third quarter of the year 2017. Sales growth in the third quarter of 2017 was largely due to the Infrastructure sector (49\%) Consumer Goods (19\%), and the health sector $(12 \%)$.

\section{Rate BI 7-Day Repo}

BI 7-Day Repo is a policy interest rate that reflects the stance or monetary policy stance determined by Bank Indonesia and announced to the public. The use of the BI 7-Day Repo Rate as a reference interest rate takes effect on August 19, 2016. Prior to this period, the reference interest rate uses the BI Rate.

The BI 7-Day Repo set during the study period tended to decrease. The following is BI Rated Indonesia from 2015-2018. Based on the Board of Governors' Meeting (RDG) of Bank Indonesia on 14-15 December 2016 decided to keep the BI 7-day Reverse Repo Rate (BI 7-day RR) fixed at 4.75\%, with the Deposit Facility interest rate fixed at $4.00 \%$ and the Lending Facility remained at $5.50 \%$, effective since December 16, 2016. The policy is consistent with efforts to optimize the recovery of the domestic economy while maintaining macroeconomic and financial system stability, amid the uncertainty of global financial markets. Bank Indonesia views that the easing of monetary and macroprudential policies that have been carried out previously can continue to drive the momentum of domestic economic growth. 
Going forward, Bank Indonesia will remain vigilant of a number of risks, both stemming from global economic and financial uncertainties, particularly related to the direction of US and China policy, as well as from within the country primarily related to the effect of rising administered prices on inflation (20). Bank Indonesia (BI) has been quite aggressive in reducing its benchmark interest rate during 2016. In total, there have been 150 basis points of interest rate reductions occurring until the transition to the BI 7 Days Reverse Repo Rate is now $4.75 \%$.

Meanwhile in 2017 Bank Indonesia (BI) cut back the benchmark interest rate (BI rate) by 0.25 percent to 4.5 percent. Previously, the BI rate for 10 months held at 4.75 percent. This decline in interest rates is consistent with the loosening of monetary policy and the low realization and forecast of inflation in 2017 and 2018 within the specified target range. This policy is consistent with efforts to maintain macroeconomic and financial system stability and also support the recovery of the domestic economy while taking into account the dynamics of the global and domestic economy. Bank Indonesia considers that the easing of monetary policy that has been taken previously is sufficient to continue to drive the momentum of domestic economic recovery amid better macroeconomic stability. Going forward, Bank Indonesia will remain vigilant of a number of risks, both from global sources related to the normalization of monetary policy in several developed countries and geopolitical risks, as well as from within the country especially regarding ongoing corporate consolidation and weak banking intermediation (Bank Indonesia, 2017).

But at the end of 2018 based on the Board of Governors' Meeting (RDG) of Bank Indonesia on 19-20 December 2018 decided to maintain the BI 7-day Reverse Repo Rate (BI7DRR) of $6.00 \%$, the Deposit Facility interest rate of $5.25 \%$, and the interest rate Lending Facility interest of $6.75 \%$. Bank Indonesia believes that the policy rate is still consistent with efforts to reduce the current account deficit to within safe limits and maintain the attractiveness of domestic financial assets, including considering trends in global interest rate movements in the coming months. Bank Indonesia also continues to strengthen coordination with the Government and relevant authorities to maintain economic stability and strengthen external resilience, including to control the current account deficit so that it drops to around 2.5\% of GDP in 2019 (Bank Indonesia, 2018).

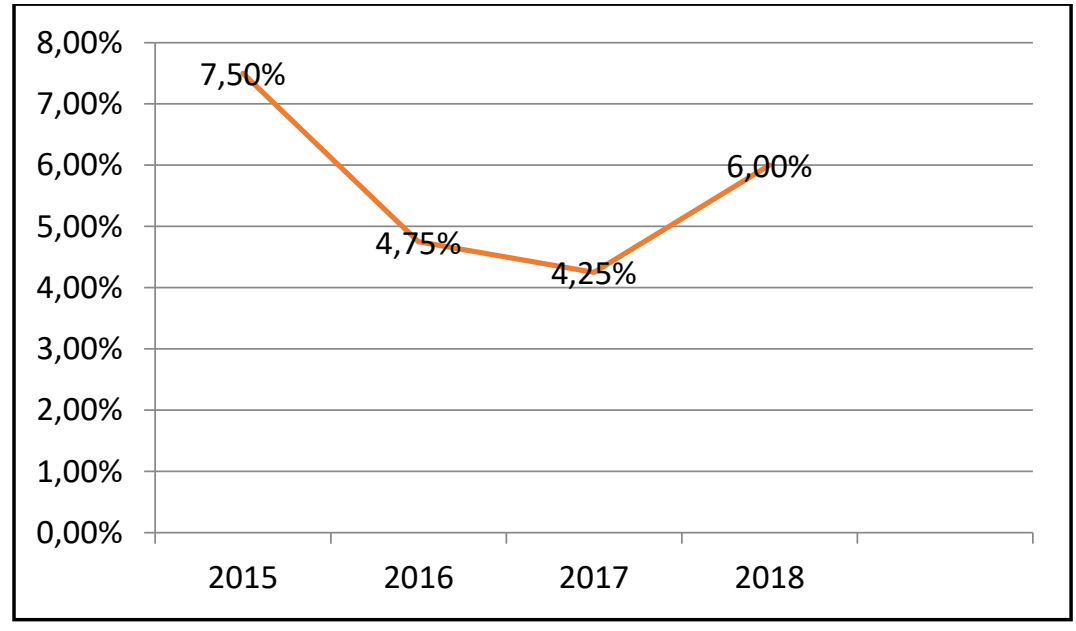

Source : Report From Bank Indonesia 2015-2018

Figure 2. BI -7 Day Repo per Desember 2015-2018 


\section{Inflation}

Inflation according to Hasyim (Hasyim, 2016) is all economic symptoms that indicate an increase in the level of prices generally in a sustainable manner. Conditions for inflation that occur in general and continuous price increases. Sources of inflation data in Indonesia are obtained from the official website of Bank Indonesia.

Inflation in Indonesia in the period of observation (2015 to 2018) tends to stable. Inflation in 2017 is maintained and remains low around 3.5\% (yoy) and is within the inflation target range of $4 \pm 1 \%$. In 2018 inflation will remain low and stable within the 2018 inflation target.

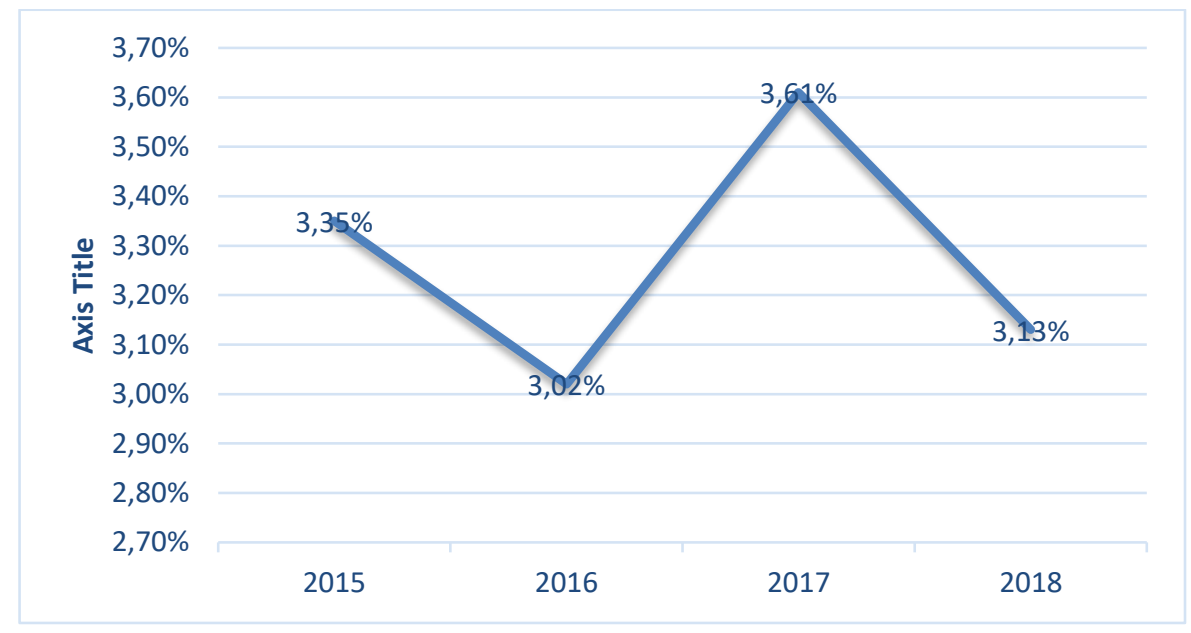

Source : Report From Bank Indonesia 2015-2018

Figure 3. Inflation per Desember 2015-2018

\section{Profitability, Firm Size, and Macroeconomic Variable Affect Yield to Maturity of Corporate Sukuk}

Based on the chow test, it was found that the fixed effect model was better than the common effect model and based on the results of the hausman test it was found that the fixed effect model was better used than the random effect model. Thus the model used is the fixed effect model, so that the regression test will get a t test that will partially test the influence of variables. T test results can be seen in table 6 .

Table 6. t- Test

\begin{tabular}{llll}
\hline \multicolumn{1}{c}{ Variable } & $\mathrm{t}$ count & $\mathrm{t}$ table & Prob t \\
\hline Profitability & 1.131893 & 1,65810 & 0.2620 \\
Firm Size & 1.694792 & 1,65810 & 0.0951 \\
BI 7 Day Rate & 13.36008 & 1,65810 & 0.0000 \\
Inflation & 3.462468 & 1,65810 & 0.0010 \\
\hline
\end{tabular}

The results of this research show that there is no influence given the profitability variable which is projected with Return on Assets (ROA) on the yield of ijarah sukuk. 84 | The International Journal of Business Review (The Jobs Review) Vol.2 | No.2 |2019 
investing sukuk which is basically in the form of investor debt does not race against the profitability ratios of a company because profitability has more influence on stock returns than bond returns in long-term investments, because payment of compensation for bonds is considered a cost (interest costs) and The cost calculation is done before the profit calculation, while the payment of compensation for shares (dividends) is done after the calculation of profit so that profitability does not affect the yield to maturity of the bond. The results of this study are in line with research conducted by Yahya (Yahya, 2017).

The research indicate that there is a significant negative effect between firm size variables and yield to maturity of ijarah sukuk. a large company, then the assets owned by a company will also be able to use their funds, either as a company backup or smooth fulfillment of obligations. In addition, large companies have good prospects in a relatively long period of time, are more stable and are more able to generate profits compared to companies with small total assets so that companies with large total assets have a low level of risk and low returns offered

The results also indicate that there are positive and significant influences give the BI 7 day rate to the ijarah sukuk yield. It reflects that the BI rate has an effect on large yield, this is because if the BI rate an increase will be responded with the increased rate of return that investors are hinting at because bond prices tend to fall due the rise in the $\mathrm{BI}$ interest rate, in other words if the BI rate increases then the amount yield to maturity required by investors will also increase.

Then, the results of this research also indicate that there is a negative and significant effect given by the inflation variable on sukuk yield. Low inflation is inflation of less than $10 \%$. This indicates that the existing investment has a relatively small level of risk while sukuk which has a smaller risk gives a small yield to maturity, so that with inflation the low category of inflation can have a negative impact on yield to maturity

Low and stable inflation is a deep basic prerequisite achieve sustainable economic growth and community welfare.

\section{CONCLUSION}

The conclusion in this study shows that there is a trend of decreasing yield to maturity of sukuk from 2015-2018 based on sources obtained from the Indonesia Bond Pricing Agency. The largest average yield to maturity given in the observation period is produced by PT. Summarecon Agung and the lowest are owned by PT. Indosat. Microeconomic conditions that are described by company conditions illustrate the fluctuating profitability of issuers and also the fluctuating condition of company size. As well as the macro variables, the BI Rate and inflation show a downward trend over the period of the research year.

This study shows that the profitability variable does not affect the yield, firm size variables in the $t$ test results there is no significant effect on the yield of ijarah sukuk, the BI 7 day rate variable gives significant positive effect on sukuk yield and inflation variables have a negative and significant effect on ijarah sukuk yield. From the results of these studies can be used for investors to give consideration to investors in sukuk investing. Where the yield in ijarah sukuk is influenced by two macro variables namely the BI rate variable and inflation so that investors can consider the returns and risks that would be accepted if they invested their money in sukuk instruments. Suggestions in this study should use other microeconomic variables that show the performance of issuers with respect to debt, such as the Debt to Equity Ratio ratio. As well as the use of more variable macro variables such as Domestic Product Revenue (GDP). 
SUCI APRILLIANI UTAMI \& YANA ROHMANA/Does Profitability, Firm Size, and Macroeconomic Variable Affect Yield to Maturity of Corporate Sukuk?

\section{REFERENCES}

Abdel-Khaleq, A. H., \& Richardson, C. F. (2007). New horizons for Islamic securities: emerging trends in sukuk offerings. Chicago Journal of International Law, , 2.

Ahmad, N., Daud, S. N. M., \& Kefeli, Z. (2012). Economic Forces and the Sukuk Market. Procedia - Social and Behavioral Sciences, 65, 127-133. https://doi.org/10.1016/J.SBSPRO.2012.11.101

Al-raeai, A. M., Zainol, Z., \& Abdul Rahim, A. K. (2018). The Role of Political Risk and Financial Development Factors on Sukuk Market Development of Gulf Cooperation Council (GCC) Countries. Asian Journal of Finance \& Accounting, 10(1), 242. https://doi.org/10.5296/ajfa.v10i1.13106

Alam, N., Hassan, M. K., \& Haque, M. A. (2013). Are Islamic bonds different from conventional bonds? International evidence from capital market tests. Borsa Istanbul Review, 13(3), 22-29. https://doi.org/10.1016/j.bir.2013.10.006

Bank Indonesia. (2017). Infografis Kebijakan Moneter Bank Indonesia. https://www.bi.go.id/id/ruang-media/siaran-pers/Pages/sp_199517.aspx

Bank Indonesia. (2018). Infografis Kebijakan Moneter Bank Indonesia. https://www.bi.go.id/id/ruang-media/siaran-pers/Pages/sp_209618.aspx

Bhuiyan, R. A., Rahman, M. P., Saiti, B., \& Mat Ghani, G. (2018). Financial integration between sukuk and bond indices of emerging markets: Insights from wavelet coherence and multivariate-GARCH analysis. Borsa Istanbul Review, 18(3), 218-230. https://doi.org/10.1016/j.bir.2017.11.006

Boutti, R. (2014). Sukuk and Bond Performance in Malaysia.

Ekananda, M. (2014). Analisis Ekonometrika Data Panel. Mitra Wacana Media.

Ferdinand, A. (2014). Metode Penelitian Manajemen. Badan Penerbit Universita Diponegoro.

Haryanto, S. H. A. \&. (2012). Analisis Faktor-Faktor yang memepengaruhi Yield Obligasi Korporasi. Diponegoro Journal of Management.

Hassan, K. A. (n.d.). Comparison between Sukuk and Conventional Bonds: Value at Risk Approach. http://ssrn.com/abstract=2215194

Hasyim, A. I. (2016). Ekonomi Makro. Prenadamedia Group.

IIFM Sukuk Report. (2018). (2019). A Comprehensive study of the global sukuk market (6th ed.). https://www.iifm.net/iifm-publishes-its-annual-sukuk-report-2019-usd-1232-billion-sukuk-issued-globally-in-2018/

Indonesia Bond Pricing Agency. (2019). Yield to Maturity Sukuk Ijarah and Mudharabah.

Jobst, A., Kunzel, P., Mills, P., \& Sy, A. (2008). Islamic bond issuance: what sovereign debt managers need to know. International Journal of Islamic and Middle Eastern Finance and Management, 1(4), 330-344. https://doi.org/10.1108/17538390810919637

Krichene, N. (2012). Islamic capital markets: Theory and practice. John Wiley \& Sons.

Naifar, N., \& Mseddi, S. (2013). No TitleSukuk Spreads Determinant and Pricing Model Methodology. Afro-Asian Journal of Finance and Accounting, 241-257. https://scholar.google.com/citations?user=ZhbgTmMAAAAJ\&hl=en\#d=gs_md_cita$\mathrm{d} \& \mathrm{u}=\% 2 \mathrm{Fcitations} \% 3 \mathrm{Fview} \_$op $\% 3 \mathrm{Dview}$ _citation\%26hl\%3Den\%26user\%3DZhbgT mMAAAAJ\%26citation_for_view\%3DZhbgTmMAAAAJ\%3AWF5omc3nYNoC\%2 6tzom\%3D-420

Naifar, N. (2016). Modeling dependence structure between stock market volatility and sukuk yields: A nonlinear study in the case of Saudi Arabia. Borsa Istanbul Review, 16(3), 157-166. https://doi.org/10.1016/j.bir.2016.01.005

86 | The International Journal of Business Review (The Jobs Review) Vol.2 | No.2 | 2019 
Nisar. (2010). How Sukuk works: Introduction, structuring and application of Sukuk bonds.

Noor, J. (2017). Metode Penelitian: Skripsis, Tesis, Disertasi, dan Karya Ilmiah. Kencana.

Oseni, U.\&Hassan, M. . B. (2015). No Title. Journal of Banking Regulation, 16:220. https://doi.org/https://doi.org/10.1057/jbr.2014.3

Otoritas Jasa Keuangan. (2015). Peraturan Otoritas Jasa Keuangan Nomor 18/POJK.04/2015.

Puspa, M., \& Duasa, J. (2017). Sovereign Sukuk Pricing Analysis: Do Macroeconomic Variables Matter? IIUM Journal of Economics and Management, 25(3), 513-528.

Razak, S. S., Saiti, B., \& Dinç, Y. (2018). The contracts, structures and pricing mechanisms of sukuk: A critical assessment. Borsa Istanbul Review. https://doi.org/10.1016/j.bir.2018.10.001

Rohmana, Y. (2013). Ekonometrika Teori dan Aplikasi dengan EViews. Laboratorium Pendidikan Ekonomi dan Koperasi Universitas Pendidikan Indonesia.

Tandelilin, E. (2017). Pasar odal Mnajemen Portofolio dan Investasi. In Jurnal Manajemen dan Bisnis MEDIA EKONOMI VolumeXVII. Kanisius.

Wilson, R. (2008). Innovation in the structuring of Islamic sukuk securities. Humanomics, 24(3), 170-181. https://doi.org/10.1108/08288660810899340

Yahya, W. F. (2017). Analisis Faktor - Faktor yang Mempengaruhi Yield Obligasi. Jurnal Ilmu Dan Riset Manajemen Volume 6, Nomor 8.

Zulkhibri, M. (2015). A synthesis of theoretical and empirical research on sukuk. Borsa Istanbul Review, 15(4), 237-248. https://doi.org/10.1016/j.bir.2015.10.001 